\title{
Investigation of Mechanical Properties and Chemical Composition of Root Vegetables on the Example of Carrot Roots
}

\author{
Gorzelany Józef ${ }^{1}$, Matłok Natalia² \\ Faculty of Biology and Agriculture, University of Rzeszow, Poland \\ joshiprasadreddy@yahoo.com
}

\begin{abstract}
Learning the mechanical properties of biological materials has very important significance in practice, and allows to find solutions for essential problems connected e.g. with estimation of degree of resistance against damage, determining the required storage conditions, comparison of varieties and assessing the degree of maturity.

Carrots and other vegetable products in the process of harvesting, transportation and storage are frequently subject to mechanical damage. Based on the laboratory investigation carried out the analysis of chemical composition has been made, as well as the estimation of mechanical properties of the carrot storage roots

There have been also executed the basic examinations of chemical composition of carrot roots: water, ash and volatile substance contents, as well as values of chemical element ( $\mathrm{C}, \mathrm{H}, \mathrm{N}$ and $\mathrm{S}$ ) contents.

The investigations of carrot storage roots have referred to the determination of the carrot root resistance against mechanical damage occurring in the process of penetration with a punch of $5 \mathrm{~mm}$ diameter and uniaxial compression of peel and core (free samples). Based on the obtained results of investigations there have been also determined elasticity parameters of carrot root peel and core in form of destruction stress and apparent Young's modulus.
\end{abstract}

Keywords: carrots, chemical properties, destruction stress, Young modulus

\section{INTRODUCTION}

Olericulture is the branch of farming that is engaged in growing vegetables in open ground, greenhouses and field tunnels [Czachor, 2006]. One of the characteristic confirming the importance of olericulture for food industry is the annual production volume, which in turn forms the significant Poland's contribution to production of particular vegetables and fruits worldwide and in European Union as well. For many years Poland is among the worldwide and European leaders in production of many vegetables [Olewnicki, 2009]. China is the leader in vegetable production worldwide [Czachor, 2006]. Poland as the vegetable grower stands at an essential position especially in carrot production, where it has been placed at the fourth position in recent years. The same position Poland has occupied among European nations cultivating this vegetable [Nieć, 1999].

Root vegetables constitute a usable group, in which roots are the edible parts. Carrots (Daucus carota) also belong to this group. They belong also to the most frequently cultivated vegetables in Poland and worldwide as well. Due to the contents of constituents with beneficial effects upon human health, carrots are the vegetable of very great importance in human nutrition [Gajewski, 2010]. They belong to the vegetable group of greatest 
nutritional value and health-promoting value as well. They are a source of carotene (pro-vitamin A) [Bahri i Rashidi, 2009], sugars [Suojala, 2000], vitamins, as well as minerals, especially potassium, calcium, phosphorus, iron and magnesium, also contain thiamines and riboflavines [Ahmad et al., 2005; Hussain et al., 2005; Rashidi et al., 2009b]. Carrots in their composition contain 75-88 percent of water and 8.5-12.5 percent of solids [Rashidi et al., 2009b, Rashidi et al., 2009a]. High contents of water and soluble solids essentially affect the storage life, mechanical properties and quality characteristics [Mohsenin, 1986; Hussain et al., 2005; Mostofi et al., 2006; Sharma et al., 2006; Ullah et al., 2006, Rashidi et al., 2010]. Carrots are widely used for culinary purposes, both in fresh and processed form [Sady et al., 2000]. Consumption of carrots increases the resistance against blood and eye diseases [Mohsenin, 1986].

Mechanical properties of vegetables can be considered as the variety-dependent characteristics, but changes in the mechanical characteristics can be caused by the influence of different external factors, like fertilization, environmental and soil conditions, as well as diseases. The research interests in mechanical properties of vegetables result mainly from the necessity to reduce losses during harvest, transportation and storage [Bzowska- Bakalarz, 1998].

Biological materials, like vegetables and fruits are subject to different static and dynamic loads connected with harvesting, loading/unloading, transportation, sorting and other manipulations necessary in the process of preparation of the final product. During these processes the vegetables are subject to mechanical damage in form, among other, of incisions, excoriations, bruises and splits [Gołacki et al., 2006]. The vegetables under the influence of mechanical loads manifest viscoelastic properties, affected, among others, by the values of applied forces and speeds of load application [Jakubczyk and Lewicki 2003].

The majority of damage is caused by the influence of long-lasting, static compression loads. For the reason of the shape of agricultural products the contact loads have the decisive influence on the type and size of damage, due to the fact that a force is applied over small area. In case of such loads it may happen that even in a material with relatively high strength characteristics a local concentration of stresses occurs, what may lead to disturbance of integrity of the investigated object [Stopa et al., 2008]. Mechanical damage resulting from exceeding the admissible load levels cause losses due to reductions in quality levels and infection by pathogens [Blahovec, 2007]. It is estimated in regard to vegetables that few tens of percent of agricultural products are subject to damage caused by the inappropriate harvesting technology, poorly designed machines and pieces of equipment or even the process lines in the processing plants [Blahovec, 2001].

The following factors decide about vegetable resistance against mechanical damage : a vegetable variety, raw fibre contents, s pecific gravity and a degree of maturity [Bohdziewicz et al., 2009]. The shape and size of the investigated sample is also of essential importance [Marzec et al., 2008].

Many researchers have carried out the measurements and evaluations of vegetable mechanical properties, using conventional strength test methods [Gorzelany et al., 2005]. These measurements have been carried out with use of the special measuring equipment generating artificial mechanical damages [Gorzelany et al., 2000].

For the purpose of characterization of the elastic or viscous behaviour of plant tissue under the influence of axial load the models can be used, which express the dependencies between stresses and variations in dimensions along the force direction. The first trials to get mathematical notation of the processes occurring in the tested 
vegetable samples, have been undertaken in the eighties of the $20^{\text {th }}$ century [Blahovec, 1985; Peleg, 1984; Pitt, 1982; Sitkei, 1987].

Szot, Gołacki and Kęsik [Szot et al., 1978] have carried out investigations of mechanical properties of carrot roots in dependence on variety-dependent characteristics, agricultural factors and duration of storage.

Jerzy Bohdziewicz has carried out the compression tests of carrot root samples, taking into account their morphological differentiation. Then he has compared the obtained results with values of parameters of the rheological models, calculated on the base of creep and relaxation tests. |In relation to single root no essential correlation has been found between the stresses and elasticity modulus from one side and the parameters of rheological models from the other one. He has observed however from comparisons of average values of the elasticity modulus $\mathrm{E}$, dynamic viscosity $\mathrm{n}_{\mathrm{o}}$ and apparent viscosity $\mathrm{n}_{\mathrm{o}^{\circ}}$, that the differences exist in behaviour of tissues and axial cylinder under the influence of load [Bohdziewicz, 2003].

Investigations have been carried out by Gorzelany and Puchalski, with use of the non-destructive methods, in order to examine the resistance of sugar beet roots against mechanical damage during harvesting. They have made the analysis of dependence between the perforation force and the selected parameters measured with use of destructive methods. Based on the results obtained for 30 day storage period the dependence has been stated between the investigated characteristics, determined with use of the non-destructive methods and the destructive ones. In the process of storage the decreases have been stated in values of penetration forces for root peel, root tissue and values of maximum force impulses [Gorzelany et al., 2000].

Fencher and Bentini have used an electronic root model for the purpose of estimation of damage to sugar beet crops in field conditions, in dependence on the machine working speed. The "electronic beet" is very useful measuring tool that allows to assess the influence of the working parts and assemblies of the machine to mechanical damage [Bentini et al., 2002; Fechner et al., 2000].

Lentas and Wiatrowa-Rejchert have carried out investigations to examine the influence of blanching parameters on mechanical properties and colour of dried celery roots. It has been stated that reduced temperature and longer blanching time have led to increased tissue hardness in the blanched, dried and subsequently rehydrated products [Lentas et al., 2009].

Jakubczyk and Uziak have carried out investigation of compression, relaxation and shearing of potatoes and sugar beets. It has been stated that the strength test, among other compression tests and shearing tests, directly concerning such the property, as hardiness, have been good indicators of the product texture. The obtained values of maximum stress and shearing force, images of compression and shearing curves have indicated high values of potato and sugar beet hardiness [Jakubczyk et al., 2006]. Bzowska-Bakalarz has undertaken in her work the trial to determine the strength limits of sugar beet tissue, based on destructive stresses and cracking energy with use of the scanning microscope [Bzowska- Bakalarz, 1998]. Learning the rheological properties of vegetables has very important practical significance and allows to resolve many essential problems connected e.g with assessment of levels of resistance to damage, determination of storage conditions, comparison of varieties and assessing the degree of maturity [Blahovec, 2001]. It also brings very valuable information both for designers of agricultural machines, especially for processing purposes, as well as for specialists in genetics and breeders of new plant varieties [Stopa et al., 2008]. 
The objective of the investigation was to determine the basic elasticity parameters of carrot root peel and core, i.e. the destruction stress and apparent Young's modulus, and determination of chemical composition of roots of the selected carrot varieties at the angle of resistance to mechanical damage.

\section{Methods AND MEASURING EQUIPMENT}

\section{Investigation of Mechanical Properties}

\section{Characteristics of the research stand and the measurement working parameters}

Measurements of carrot storage root resistance against mechanical damage have been carried out on the Zwick/Roell strength testing machine (Fig. 1). This machine is composed of a measuring head provided with a converter and a strain gauge, of a base and a movable beam of a digital reader. Results have been recorded automatically by means of a printer operated together with the machine. In the measurement process the measuring head generates signals corresponding to values of the compression force and sends it through the connector to the pre-amplifier, then to the digital reader and the printer.

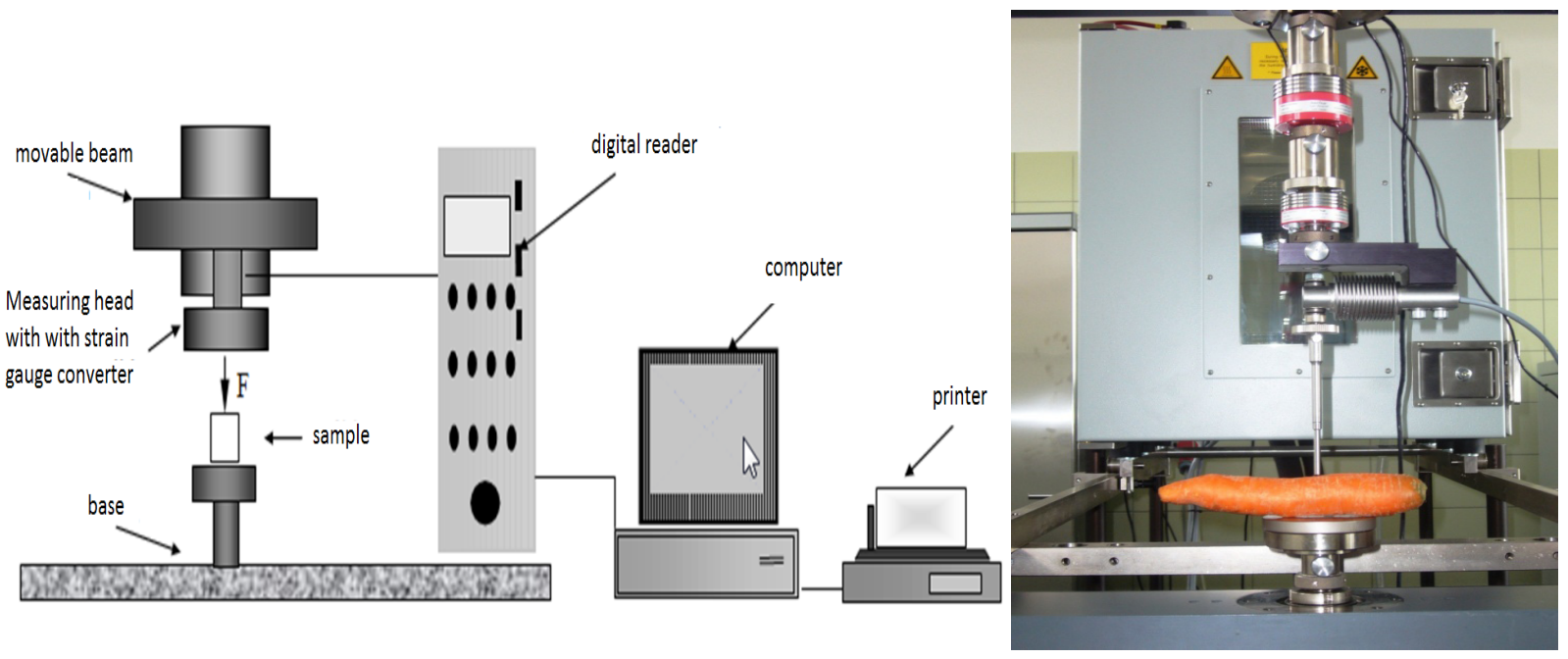

Fig.1 Scheme of a measurement stand - Zwick/Roell strength testing machine.

Penetration forces for carrot root peel and core.

The investigations have been carried out for the following stationary parameter values:

$>\mathrm{F}_{\mathrm{v}}=2 \mathrm{~N}$ (preliminary force)

$\mathrm{V}_{1}=40 \mathrm{~mm} / \mathrm{min}$ (speed of the settling and return movement of the beam/sensor assembly)

$\mathrm{V}_{2}=-20 \mathrm{~mm} / \mathrm{min}$ (speed of the beam/sensor assembly during measurement)

Punch diameter $\varphi=5 \mathrm{~mm}$

Parameters registered on the printer: 
$>\mathrm{F}_{\max }=$ maximum force of the root peel penetration and destruction force of the free sample $[\mathrm{N}]$

$>\mathrm{L}_{\max }=$ maximum strain directly before peel penetration and before complete destruction (free samples) $[\mathrm{mm}]$

$\mathrm{X}=$ average value of maximum forces and strains for a series of measurements

Process of measurements of the carrot root resistance against mechanical damage.

The investigations have been carried out with use of the fresh vegetal material directly after harvest. In order to determine the influence of the peel and core sampling method and the part of root selection for sampling on the mechanical property variations, the samples have been cut out from three parts of the carrot roots: from the upper parts, central parts and bottom ones along the longitudinal root axis and in the transversal direction. The sample cuts have been $10 \mathrm{~mm}$ high and $8 \mathrm{~mm}$ in diameter. Each measurement series have comprised ten samples of peel and core from each part of root and two directions of sample cutting. After each series the measurement results have been printed and together with calculation of the average values of maximum destruction forces, strains directly before the moment of sample penetration or destruction, work (energy) and Young's modulus

\section{Chemical Analysis of Carrot Storage Roots}

Determination of number of samples and sample preparation for chemical analysis

The number of samples for each carrot variety have been determined with use of the Student's expression [Szczepański, 1987]:

Where:

$$
r \geq 2 \cdot\left[\frac{t_{\alpha} \cdot V}{d}\right]^{2}
$$

$r$ - Number of repetitions in request;

$t_{\alpha} t_{\alpha}$-Student's t value for the $\alpha$ statistical significance; for $\alpha=0.95 \mathrm{t}$ is 2.030 ;

$\mathrm{d}[\%]$ - assessment precision, i.e. a standard deviation of the measurement results, obtained from the series of repetitions for the same material, has amounted $2 \%$;

V\% - value of the coefficient of variation for 35 pieces of vegetables in the test sample, has amounted $2.1 \%$.

Therefore, it results from the calculations that the number of repetitions in request should amount for each carrot variety:

$$
r \geq 2 \cdot\left[\frac{2,030 \cdot 2,1 \%}{2 \%}\right]^{2}=9,08 \approx 9 .
$$

The research material has been subject to homogenization, i.e. each sample of particular carrot variety has been separately blended in the laboratory appliance for blending biological materials, and then the whole sample has been divided into two equal parts. Three samples for thermo-gravimetric tests has been initially taken from the first part in order to determine material humidity and ash contents, and then subsequent three samples for the purpose of determination of contents of volatile substances at the subsequent test stage. 
Characterization of the research stand and the process of determination of humidity and ash contents with use of TGA method

Determination of humidity and ash contents has been carried out with use of thermo-gravimetric method in LECO - TGA701 apparatus (Fig. 2). It is provided with an automatic sampler at the 19 position (fig. 3), automatic weight measurement with $0.0001 \mathrm{~g}$ sensitivity, $0.02 \%$ measuring precision and measuring range from $20^{\circ} \mathrm{C}$ to $1000^{\circ} \mathrm{C}$.

Working procedure consists in placing a sample weighting about 1 gram in a measurement tray, so called crucible, and then setting the working parameters of the equipment. Ambient temperature has been the initial parameter. Then the sample has been heated up to $60^{\circ} \mathrm{C}$ - this has been a procedure of preliminary drying of a material with increased water contents. Then the temperature has been increased to $105^{\circ} \mathrm{C}$ (in such a case the samples have not been used yet in the subsequent tests, so the $75^{\circ} \mathrm{C}$ criterion has not had to be met). In $105^{\circ} \mathrm{C}$ temperature the samples have been dried in the air atmosphere and successively weighted until $0.01 \%$ value (so called comparator value) of water contents decrease parameter has been observed between two subsequent weightings. After this the samples have been considered to be free of water, and the application has automatically calculated the weight humidity of the vegetable. Ash contents has been determined through heating up the dried material to $600^{\circ} \mathrm{C}$ and burning it in the nitrogen atmosphere with use of $0.01 \%$ comparator value.

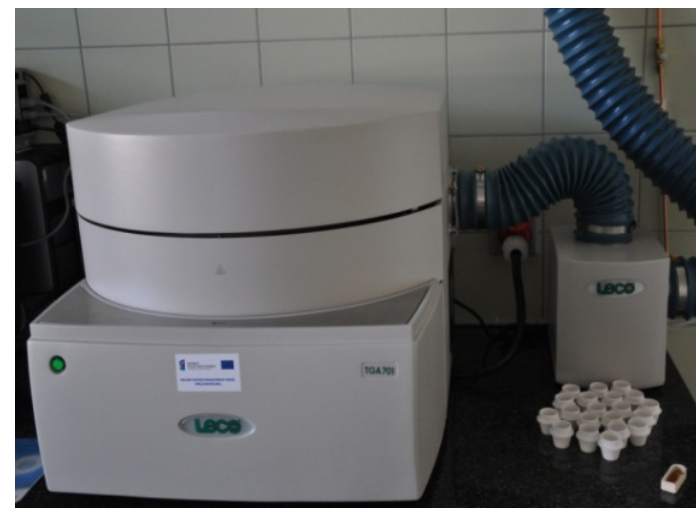

Fig2. A set of equipment for thermo-view upon an automatic sampler

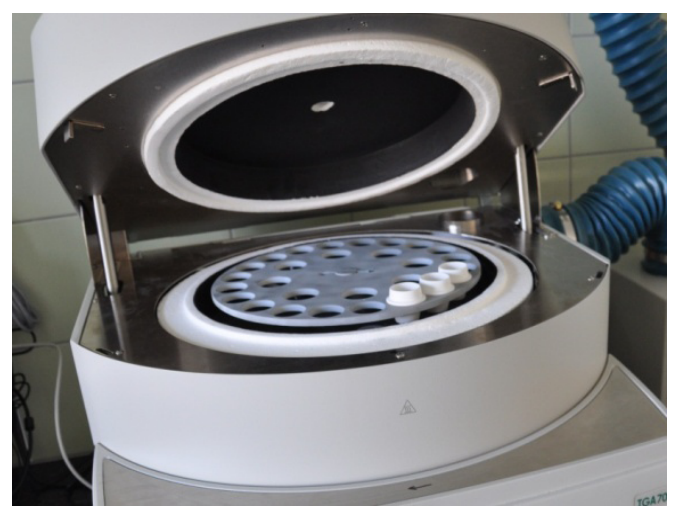

Fig3. TGA instrument with open cover an gravimetric measurements

\section{Characterization of the calorimetric investigations}

The blended (and homogenized) pulp has been dried in $70^{\circ} \mathrm{C}$ temperature, with use of a laboratory drier with forced circulation of air, for a period of 4 hours until completely dried. Humidity control before subsequent stages of analysis has consisted in using the TGA again in order to make sure the sample is completely free of water. After complete drying the sample material has been milled in a ball mill (Fig. 4). Then the material prepared in such a way has been divided into 9 samples, used subsequently for fabrication of 1 gram tablets (Fig. 5) for the purpose of investigation of calorific value. 


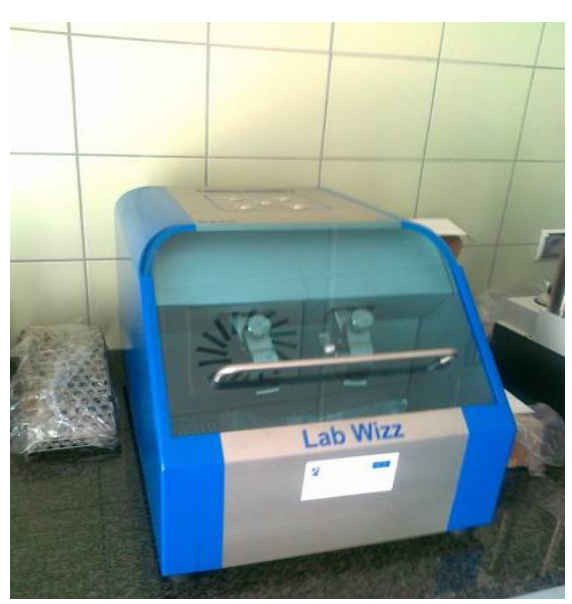

Fig4. Column ball mill

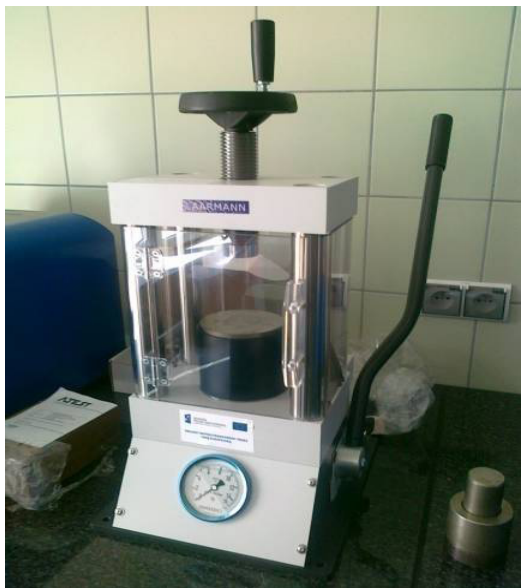

Fig5. Manual tablet press

The calorimetric investigations have been carried out with use of LECO ${ }^{\circ}$ AC500 calorimeter (Fig. 6). The calorific value is determined through burning the sample in the oxygen atmosphere, in a classic calorimetric bomb placed in water. The measurement of water temperature is carried out with an electronic thermometer of $0.0001^{\circ} \mathrm{C}$ precision. In order to assure control of the temperature of a casing, the modulation is used of rotational speed of the fan installed at a cooler, comprising a part of a water system ensuring the water temperature to be maintained at the proper level.

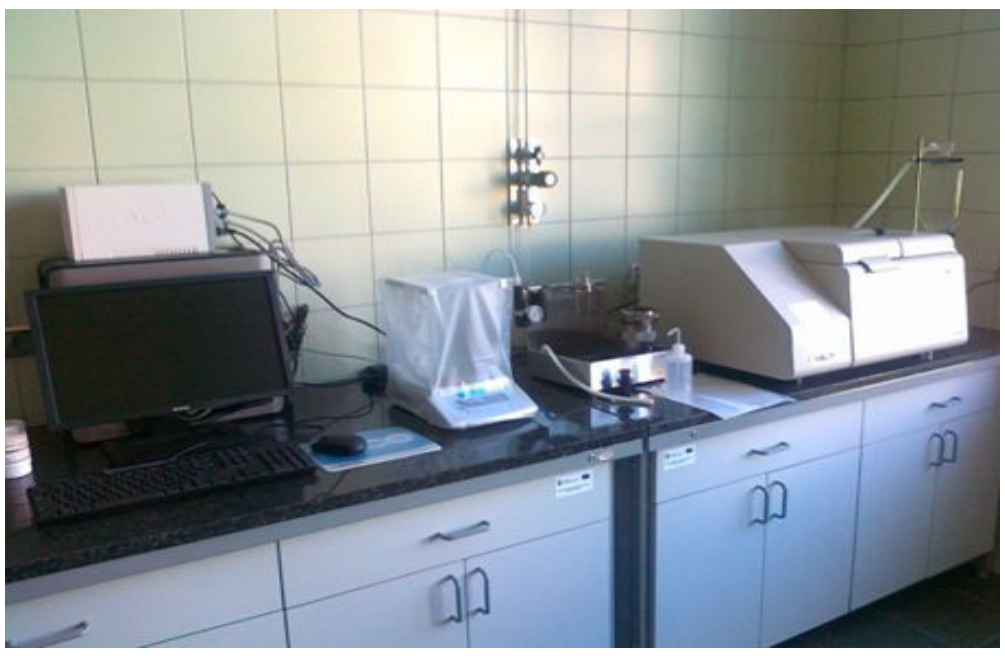

Fig6. $L E C O^{\circledR}$ AC500 calorimeter

In a isoperibol system a some degree of energy exchange can occur between a vessel surrounding a calorimetric vessel and the vessel itself. This exchange is continuously monitored by a measurement system (continues temperature readings). The occurring variations in the ambient temperature (temperature of the casing) will be 
automatically corrected in the calculations. The instrument measures the temperature of water surrounding the bomb in a continuous manner. The measurement results are then converted in the analogue-to-digital converter and registered in the memory. The temperature difference between the starting and final value is processed by the computer, giving the initial (original) value, which is displayed on the screen, and then registered in the memory together with ID code and sample weight. The result can be corrected for the reason of the ignition wire length as well as the contents of combustion facilitating additives (combustion accelerators), if any have been used. Additional corrections are made in case when sulphur, nitrogen, humidity and ash contents are determined for the sample.

The process of determination of carbon (C), hydrogen (H), nitrogen (N) and sulphur $(S)$ contents

The remaining six samples in a milled form have been subject to analysis in the TruSpec instrument for the following purposes:

Determination of sulphur contents,

Determination of carbon, nitrogen and hydrogen contents with use of the CHN module (Fig. 7)

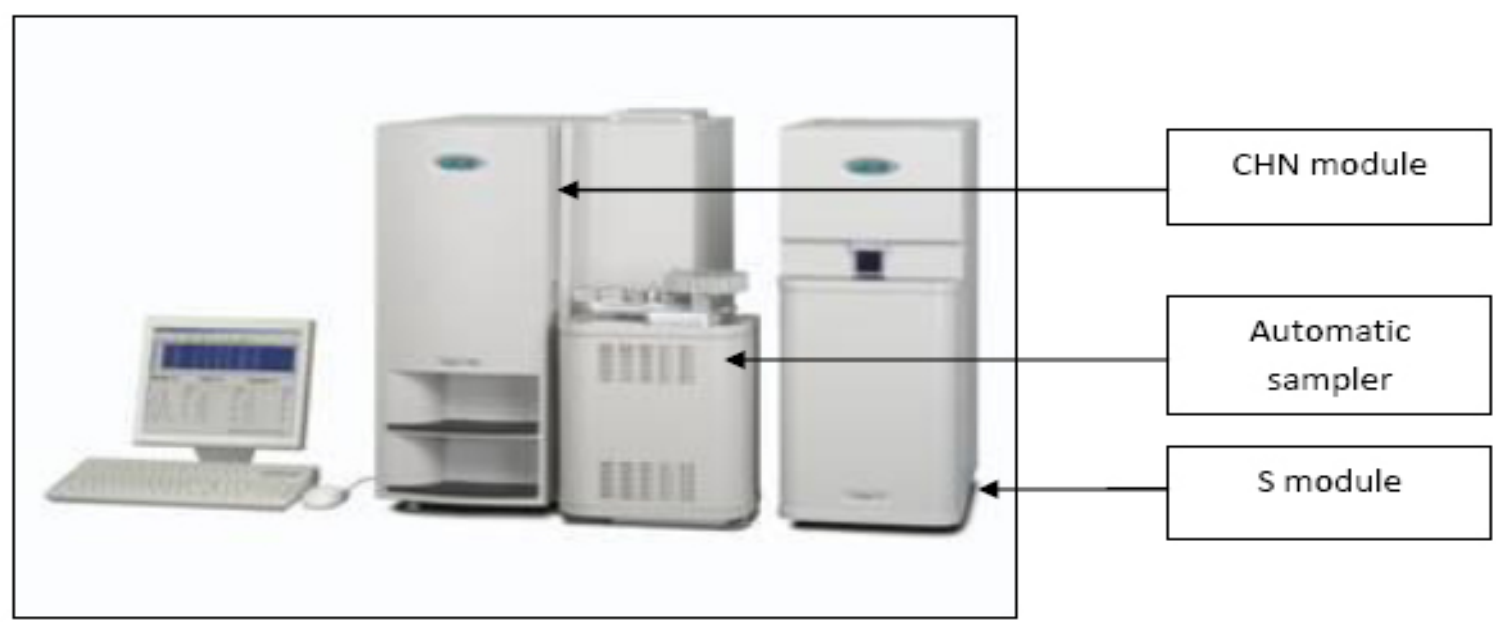

Fig 7. TruSpec ${ }^{\mathrm{TM}}$ instrument with the sulphur and $C H N$ modules pointed out.

Operation of the TruSpec ${ }^{\mathrm{TM}}$ series analysers, used for contemporary determination of carbon, hydrogen and nitrogen contents, is based on rules of the Dumas method, also known as the method of high temperature combustion in oxygen. This method guaranties the contents of all these chemical elements to be determined in the time not longer than 4 minutes. Further the sulphur analysing module can be combined with the analyser of any configuration. It can be operated independently of CHN analysers, using its own resistive oven working in typical temperature of $1350{ }^{\circ} \mathrm{C}$. The determination of sulphur contents is possible during the time of two minutes. The cycle comprises three parts: rinsing, combustion and determination of S contents. In the first step the sample placed in the tin capsule is thrown into hermetic lock for removal of all gases captured during sample loading. The whole gas system is subject to rinsing. After termination of rinsing the sample gets from the lock to the ceramic crucible placed inside the combustion tube. High temperature combined with the flow 
of pure oxygen provides rapid and efficient combustion of the investigated material. Combustion products flow then through the secondary oven, filter and condensing device in order to ensure complete combustion and water vapour removal, and finally are collected in the ballast tank. This ensures the combustion products to be completely homogenized, what is necessary for precise gas contents determination. The homogenized gases from the ballast tank flow through the series of IR detectors, and then about $3 \mathrm{~cm}^{3}$ portion of these gases is mixed with pure helium. The gas mix prepared in such a way flows through the catalytic oven, where reduction of $\mathrm{NO}_{x}$ to $\mathrm{N}_{2}$ occurs, and then, after removal of $\mathrm{CO}_{2}$ and $\mathrm{H}_{2} \mathrm{O}$, it gets the measurement branch of IR detector. Pure helium flows through the reference branch and the difference between thermo-conductivity of both gases enables the nitrogen contents to be determined. The final results are presented in form of percentage by weight or ppm. It is also possible to recalculate into the form of dry mass or protein contents.

\section{INVESTIGATION RESULTS}

\section{Chemical composition}

Average water contents for the investigated carrot varieties have amounted $86.54 \%$. The highest water contents in the peel and core have been observed in Anastasia $\mathrm{F}_{1}$ variety, the average humidity of which has amounted $88.23 \%$ in the investigated samples. On the other hand the lowest water contents in the carrot roots have been observed for Caradec $\mathrm{F}_{1}$ variety and it has amounted $85.20 \%$ in average. The ash contents for the investigated carrot varieties have amounted from $0.92 \%$ for Nerac $\mathrm{F}_{1}$ variety to $1.24 \%$ for Anastasia $\mathrm{F}_{1}$ variety with the average ash contents of $1.06 \%$ for all investigated carrot varieties. The volatile substances contained in the chemical composition of carrot storage roots have amounted in average $2.13 \%$ for the investigated four carrot varieties, with the highest contents of these substances, amounting $2.42 \%$ in average, observed for Nerac $\mathrm{F}_{1}$ variety, while the lowest contents of volatile substances in the chemical composition of carrot roots have been observed for Anastasia $\mathrm{F}_{1}$ variety, in which the average contents of these substances have amounted $1.62 \%$. The percentage values of average water, ash and volatile substance contents in carrot storage roots are presented in Table 1.

Table1. Chemical composition and calorific value of investigated carrot varieties

\begin{tabular}{|c|c|c|c|c|c|c|c|c|}
\hline \multirow[t]{2}{*}{ Variety } & \multirow{2}{*}{$\begin{array}{l}\text { Humidity } \\
{[\%]}\end{array}$} & \multirow{2}{*}{$\begin{array}{l}\text { Ash } \\
{[\%]}\end{array}$} & \multirow{2}{*}{$\begin{array}{l}\text { Volatile } \\
\text { substances } \\
{[\%]}\end{array}$} & \multicolumn{4}{|c|}{$\begin{array}{l}\text { Chemical element contents } \\
{[\%]}\end{array}$} & \multirow{2}{*}{$\begin{array}{l}\text { Calorific } \\
\text { value } \\
{[\mathrm{kcal} / \mathrm{g}]}\end{array}$} \\
\hline & & & & C & $\mathbf{H}$ & $\mathbf{N}$ & $\mathbf{S}$ & \\
\hline ANASTASIA $F_{1}$ & 88,2 & 1,24 & 1,62 & 41,8 & 5,87 & 0,85 & 0,023 & 3776,6 \\
\hline CARADEC F $_{1}$ & 85,2 & 1,00 & 2,23 & 41,3 & 5,26 & 1,67 & 0,029 & 3828,6 \\
\hline MAESTRO F $_{1}$ & 86,6 & 1,11 & 2,28 & 41,6 & 5,74 & 1,62 & 0,038 & 3789,4 \\
\hline NERAC F $_{1}$ & 86,1 & 0,92 & 2,42 & 41,8 & 8,76 & 1,46 & 0,035 & 3767,2 \\
\hline $\mathbf{x}$ & 86,5 & 1,06 & 2,13 & 41,6 & 6,41 & 1,40 & $\mathbf{0 , 0 3 1}$ & 3790,4 \\
\hline
\end{tabular}

It has been stated based on the chemical composition investigations carried out at the angle of carbon (C), hydrogen $(\mathrm{H})$, nitrogen $(\mathrm{N})$ and sulphur $(\mathrm{S})$ contents in the carrot storage roots (table 1), that the highest contribution to the chemical composition is from carbon. The average contents for this element in the roots of investigated varieties have amounted $41.61 \%$. The hydrogen contents in carrot roots are substantially lower and amount $6.41 \%$ in average for all investigated varieties. The highest hydrogen contents in the chemical 


\section{American Research Journal of Agriculture (ARJA)}

composition of carrot roots have been observed in Nerac $\mathrm{F}_{1}$ variety, with the value of $8.76 \%$, while the lowest value of $5.26 \%$ has been observed in Caradec $\mathrm{F}_{1}$ variety. The nitrogen contents in the chemical composition of carrot storage roots amount in average $1.40 \%$. The lowest contents of this element has been observed in Anastasia $\mathrm{F}_{1}$ variety, to which the nitrogen contributes only $0.85 \%$, while the highest contents for this element, amounting $1.67 \%$, has been observed for $\mathrm{tCaradec} \mathrm{F}_{1}$ variety. The process of chemical analysis of single sample of peel and core of carrot root of Caradec $\mathrm{F}_{1}$ variety at the angle of percentage $\mathrm{C}, \mathrm{H}$ and $\mathrm{N}$ contents, is presented in Fig. 8

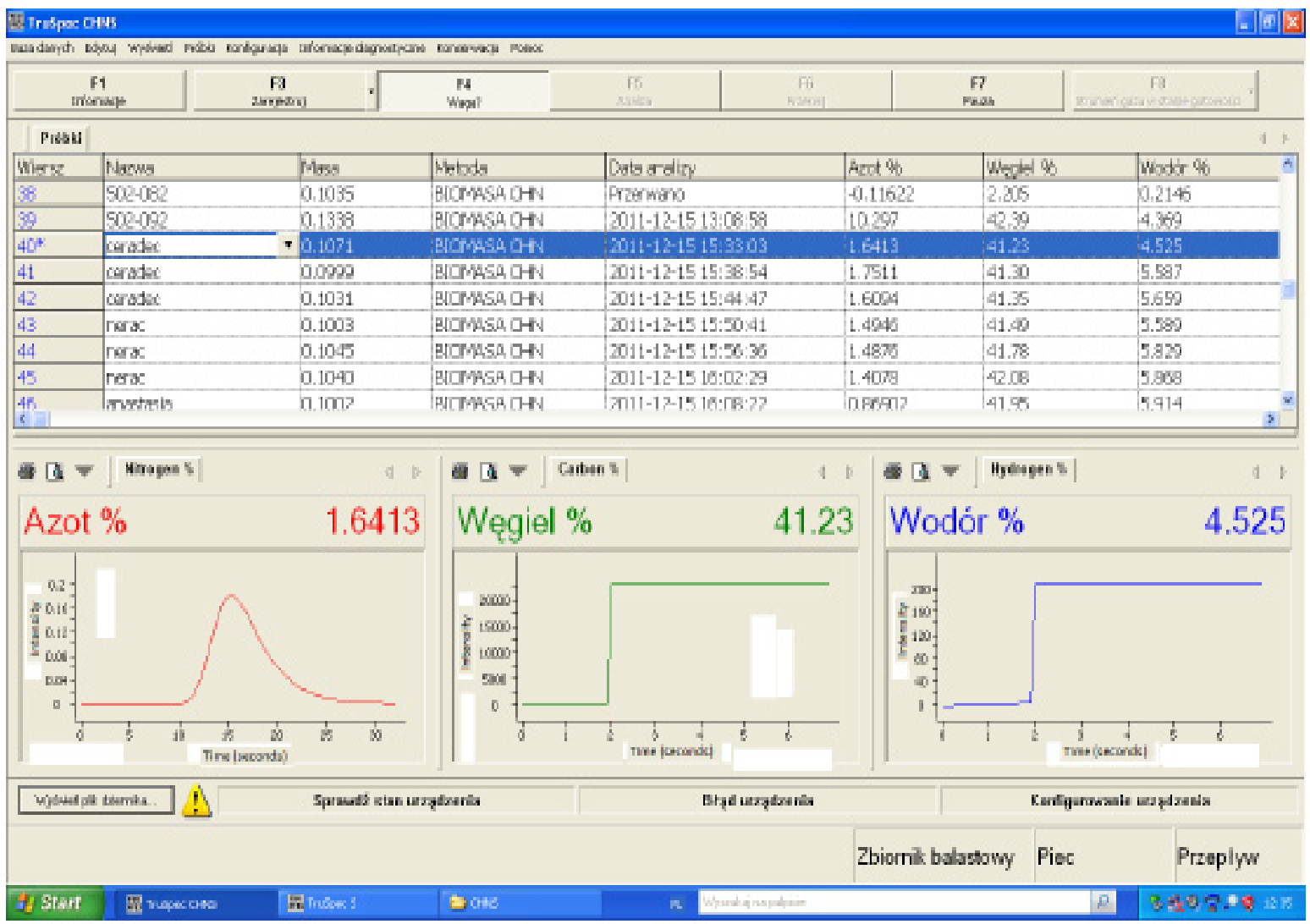

Fig8. The process of chemical analysis of single sample of the carrot root tissue of Caradec F1 variety at the angle of percentage $C, H$ and $N$ contents.

The average calorific value for all investigated carrot varieties has amounted $3790.48 \mathrm{kcal} / \mathrm{g}$. The highest calorific value of $3828.65 \mathrm{kcal} / \mathrm{g}$ has been stated for Caradec $\mathrm{F}_{1}$ variety, while the lowest calorific value has been observed in Nerac $F_{1}$ variety, for which the average calorific value of the investigated samples of this variety has amounted $3767.25 \mathrm{kcal} / \mathrm{g}$. Similar calorific values have the carrot roots of Anastasia $\mathrm{F}_{1}$ and Maestro $\mathrm{F}_{1}$ varieties, equal correspondingly $3776.61 \mathrm{kcal} / \mathrm{g}$ and $3789.41 \mathrm{kcal} / \mathrm{g}$. The average calorific values for selected carrot varieties are presented in table 1. 
American Research Journal of Agriculture (ARJA)

\section{Mechanical properties}

\section{Carrot root resistance against penetration}

The carrot varieties investigated can be characterized as having different values of the selected mechanical properties (table 2). The highest resistance against peel and core penetration has been stated for carrots of Caradec $\mathrm{F}_{1}$ variety. On the other hand the highest susceptibility to mechanical damage among the investigated carrot varieties has been stated in Anastasia $F_{1}$ variety. The average values of forces causing penetration of peel and core of carrot roots of the selected varieties differ significantly in dependence of the point of force application. It has been stated that the highest resistance against mechanical damage is observed at the upper part of carrot roots, i.e. in the vicinity of so called arms, further in the central part, while the lowest resistance is in the bottom part of the root.

Table2. Average values of the peel and core penetration force in the selected carrot varieties with the punch $5 \mathrm{~mm}$ in diameter and strains observed at the moment directly before penetration

\begin{tabular}{|c|c|c|c|c|c|c|}
\hline \multirow{2}{*}{$\begin{array}{l}\text { Point of peel } \\
\text { and core } \\
\text { penetration }\end{array}$} & \multirow{2}{*}{ Parameters } & \multicolumn{4}{|l|}{ Carrot variety } & \multirow[t]{2}{*}{$\mathbf{x}$} \\
\hline & & ANASTASIA F $_{1}$ & $\begin{array}{l}\text { CARADEC } \\
F_{1}\end{array}$ & MAESTRO F $_{1}$ & $\begin{array}{l}\text { NERAC } \\
F_{1}\end{array}$ & \\
\hline \multirow{3}{*}{$\begin{array}{l}\text { Root upper } \\
\text { part }\end{array}$} & $\mathrm{F}_{\max }[\mathrm{N}]$ & 78,75 & 88,07 & 85,94 & 85,71 & 84,62 \\
\hline & $\mathrm{L}_{\max }[\mathrm{mm}]$ & 3,90 & 4,80 & 4,50 & 4,60 & 4,45 \\
\hline & $\delta[\mathrm{MPa}]$ & 4,22 & 4,72 & 4,61 & 4,59 & 4,54 \\
\hline \multirow{3}{*}{$\begin{array}{l}\text { Root central } \\
\text { part }\end{array}$} & $\mathrm{F}_{\max }[\mathrm{N}]$ & 72,32 & 76,47 & 70,15 & 72,08 & 72,76 \\
\hline & $\mathrm{L}_{\max }[\mathrm{mm}]$ & 4,00 & 4,40 & 3,60 & 4,70 & 4,18 \\
\hline & $\delta[\mathrm{MPa}]$ & 3,88 & 4,11 & 3,76 & 3,86 & 3,90 \\
\hline \multirow{3}{*}{$\begin{array}{l}\text { Root bottom } \\
\text { part }\end{array}$} & $\mathrm{F}_{\max }[\mathrm{N}]$ & 60,15 & 62,52 & 59,49 & 61,83 & 60,99 \\
\hline & $\mathrm{L}_{\max }[\mathrm{mm}]$ & 4,50 & 4,10 & 4,70 & 4,30 & 4,40 \\
\hline & $\delta[\mathrm{MPa}]$ & 3,22 & 3,35 & 3,19 & 3,32 & 3,27 \\
\hline \multirow{3}{*}{$x$} & $\mathrm{~F}_{\max }[\mathrm{N}]$ & 70,41 & 75,69 & 71,86 & 73,21 & 72,79 \\
\hline & $\mathrm{L}_{\max }[\mathrm{mm}]$ & 4,13 & 4,43 & 4,27 & 4,53 & 4,34 \\
\hline & $\delta[\mathrm{MPa}]$ & 3,77 & 4,06 & 3,85 & 3,92 & 3,90 \\
\hline
\end{tabular}

The average values of peel and core strain directly before penetration have amounted between $4.18 \mathrm{~mm}$ and $4.45 \mathrm{~mm}$ for the investigated carrot varieties. The average values of carrot root penetration energy have been different in dependence of the place of punch penetration. For the upper part of carrot root the values of carrot penetration energy have amounted from $162.94 \mathrm{Nmm}$ to $210.64 \mathrm{Nmm}$. The average values of penetration energy in the central part of investigated carrot roots have amounted from $136.91 \mathrm{Nmm}$ to $172.94 \mathrm{Nmm}$. The lowest average values of penetration energy have been observed in the bottom parts of carrot roots, from $127.06 \mathrm{Nmm}$ to $147.06 \mathrm{Nmm}$. The average value of peel and core destruction strain in tests of carrot penetration with $5 \mathrm{~mm}$ punch for four investigated carrot varieties has amounted 3.90 MPa. The highest value of 4.06 MPa has been stated for average destruction strain in Caradec $\mathrm{F}_{1}$ variety, while the lowest value of $3.77 \mathrm{MPa}$ has been stated for average destruction strain in Anastasia $\mathrm{F}_{1}$ variety.

Strong dependence has been stated between the average value $\mathrm{F}[\mathrm{N}]$ of peel and core penetration force and percentage contents of water and sulphur (S) in carrot roots (Fig. 9. This is a reversely proportional dependence between the average value $\mathrm{F}[\mathrm{N}]$ of peel and core penetration force in carrot roots and water contents (\%), i.e. 
American Research Journal of Agriculture (ARJA)

with increase of water contents in the chemical composition of carrot storage roots, the force of peel and core penetration decreases. The value of $\mathrm{R}^{2}$ coefficient of determination, describing this dependence, is very high and amounts 0.99 .
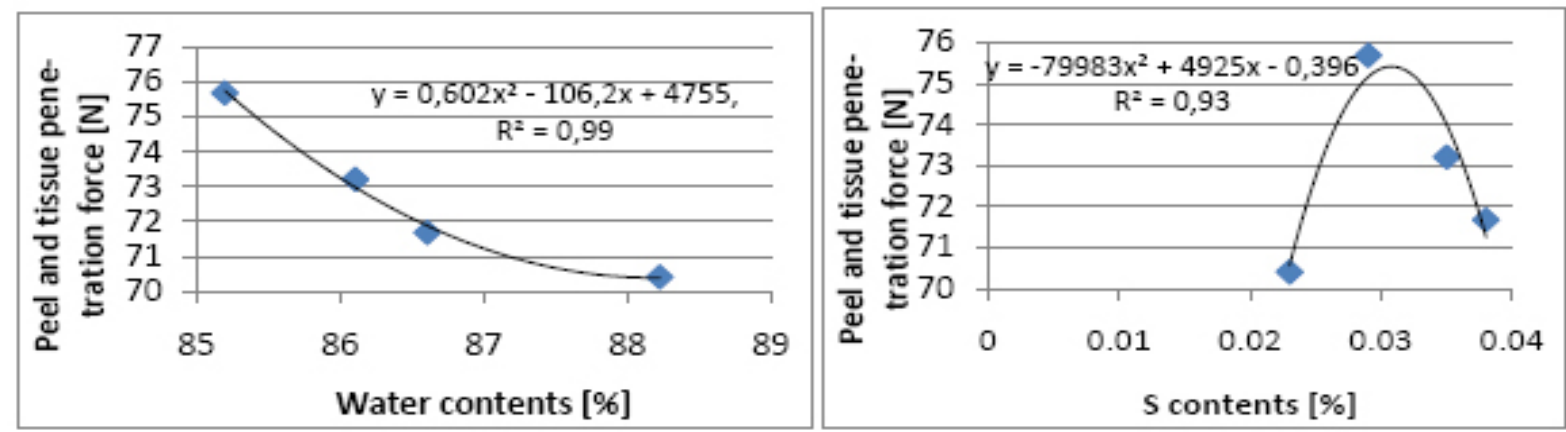

Fig9. Average values of F [N] peel and core penetration force in carrot roots in dependence of water contents (\%) and sulphur (S) contents (\%).

Dependence between the average value of $\mathrm{F}[\mathrm{N}]$ peel and core penetration force in carrot roots and average sulphur contents in the root chemical composition can be described by a second order function $\mathrm{y}=\mathrm{ax} \mathrm{x}^{2}+\mathrm{bx}-\mathrm{c}$. The value of $\mathrm{R}^{2}$ coefficient of determination, describing this dependence, is very high and amounts 0.93 .

Uniaxial compression process (free samples)

Table3. Average values of peel mechanical parameters in the investigated carrot varieties

\begin{tabular}{|c|c|c|c|c|c|c|c|c|c|c|c|c|}
\hline \multirow{3}{*}{ Variety } & \multicolumn{12}{|c|}{ Part of carrot root selection for PEEL sample cutting } \\
\hline & \multicolumn{4}{|c|}{ Upper part } & \multicolumn{4}{|c|}{ Central part } & \multicolumn{4}{|c|}{ Bottom part } \\
\hline & $\begin{array}{l}\mathrm{F}_{\max } \\
{[\mathrm{N}]}\end{array}$ & $\begin{array}{l}\mathrm{L}_{\max } \\
{[\mathrm{mm}]}\end{array}$ & $\begin{array}{l}\delta \\
{[\mathrm{MPa}]}\end{array}$ & $\begin{array}{l}{\left[\mathrm{E}_{\mathrm{u}}\right.} \\
{[\mathrm{MPa}]}\end{array}$ & $\begin{array}{l}\mathrm{F}_{\max } \\
{[\mathrm{N}]}\end{array}$ & $\begin{array}{l}\mathrm{L}_{\max } \\
{[\mathrm{mm}]}\end{array}$ & $\begin{array}{l}\delta \\
{[\mathrm{MPa}]}\end{array}$ & $\begin{array}{l}\mathrm{E}_{\mathrm{u}} \\
{[\mathrm{MPa}]}\end{array}$ & $\begin{array}{l}\mathrm{F}_{\max } \\
{[\mathrm{N}]}\end{array}$ & $\begin{array}{l}\mathrm{L}_{\max } \\
{[\mathrm{mm}]}\end{array}$ & $\begin{array}{l}\delta \\
{[\mathrm{MPa}]}\end{array}$ & $\begin{array}{l}{\left[\mathrm{E}_{\mathrm{u}}\right.} \\
{[\mathrm{MPa}]}\end{array}$ \\
\hline ANASTASIA F & 130,8 & 3,35 & 2,22 & 5,30 & 111,0 & 3,20 & 2,08 & 5,20 & 104,1 & 3,05 & 1,82 & 5,07 \\
\hline 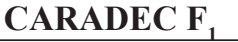 & 109,3 & 2,90 & 2,17 & 6,00 & 118,5 & 3,05 & 2,07 & 5,42 & 97,6 & 2,80 & 1,90 & 4,93 \\
\hline MAESTRO F $_{1}$ & 129,3 & 3,25 & 2,06 & 5,08 & 107,4 & 1,75 & 1,04 & 4,78 & 116,5 & 3,20 & 2,04 & 5,22 \\
\hline NERAC F $_{1}$ & 126,1 & 3,40 & 2,51 & 5,91 & 103,8 & 2,95 & 2,11 & 5,73 & 90,3 & 2,90 & 2,16 & 5,66 \\
\hline $\mathbf{x}$ & 123,9 & 3,23 & 2,25 & 5,57 & 110,2 & 2,74 & 1,81 & 5,28 & 102,9 & 2,99 & 1,98 & 5,22 \\
\hline
\end{tabular}

Table4. Average values of core mechanical parameters in the investigated carrot varieties

\begin{tabular}{|c|c|c|c|c|c|c|c|c|c|c|c|c|}
\hline \multirow{3}{*}{ Variety } & \multicolumn{12}{|c|}{ Part of carrot root selection for CORE sample cutting } \\
\hline & \multicolumn{4}{|c|}{ Upper part } & \multicolumn{4}{|c|}{ Central part } & \multicolumn{4}{|c|}{ Bottom part } \\
\hline & $\begin{array}{l}\mathrm{F}_{\text {max }} \\
{[\mathrm{N}]}\end{array}$ & $\begin{array}{l}\mathrm{L}_{\max } \\
{[\mathrm{mm}]}\end{array}$ & \begin{tabular}{|l}
$\delta$ \\
{$[\mathrm{MPa}]$} \\
\end{tabular} & $\begin{array}{l}\mathrm{E}_{\mathrm{u}} \\
{[\mathrm{MPa}]}\end{array}$ & $\begin{array}{l}\mathrm{F}_{\max } \\
{[\mathrm{N}]}\end{array}$ & $\begin{array}{l}\mathrm{L}_{\max } \\
{[\mathrm{mm}]}\end{array}$ & $\begin{array}{l}\delta \\
{[\mathrm{MPa}]} \\
\end{array}$ & $\begin{array}{l}\mathrm{E}_{\mathrm{u}} \\
{[\mathrm{MPa}]}\end{array}$ & $\begin{array}{l}\mathrm{F}_{\max } \\
{[\mathrm{N}]}\end{array}$ & \begin{tabular}{|l}
$\mathrm{L}_{\max }$ \\
{$[\mathrm{mm}]$}
\end{tabular} & \begin{tabular}{|l|}
$\delta$ \\
{$[\mathrm{Mpa}]$} \\
\end{tabular} & $\begin{array}{l}\mathrm{E}_{\mathrm{u}} \\
{[\mathrm{MPa}]}\end{array}$ \\
\hline ANASTASIA F $_{1}$ & 125,8 & 3,20 & 2,24 & 5,59 & 104,8 & 3,15 & 2,18 & 5,53 & 86,4 & 2,85 & 1,82 & 5,11 \\
\hline CARADEC F $_{1}$ & 132,8 & 3,25 & 2,62 & 6,46 & 109,6 & 3,10 & 2,25 & 5,80 & 90,4 & 2,80 & 1,90 & 5,44 \\
\hline MAESTRO F & 101,9 & 3,00 & 2,25 & 6,00 & 88,8 & 3,00 & 1,95 & 5,21 & 78,3 & 2,90 & 2,05 & 5,65 \\
\hline NERAC F $_{1}$ & 121,4 & 3,25 & 2,63 & 6,48 & 107,5 & 3,05 & 2,36 & 6,20 & 88,7 & 2,85 & 2,16 & 6,06 \\
\hline $\mathbf{x}$ & 120,5 & 3,17 & 2,43 & 6,13 & 102,7 & 3,07 & 2,18 & 5,68 & 85,9 & 2,85 & 1,98 & 5,56 \\
\hline
\end{tabular}


The Figure 10 presents the differentiation of average values of destruction force for the peel and core samples of carrot root in dependence of the part of root selection and the direction of sample cutting. This differentiation occurs both between investigated varieties and within particular variety or, in other words, between carrot core and peel and between samples selected from different part of root, i.e. from bottom, central and upper one. The highest resistance against $\mathrm{F}_{\max }[\mathrm{N}]$ destruction force has been observed in the upper part of carrot root, while the lowest resistance has been stated in core samples from the bottom part of carrot root.

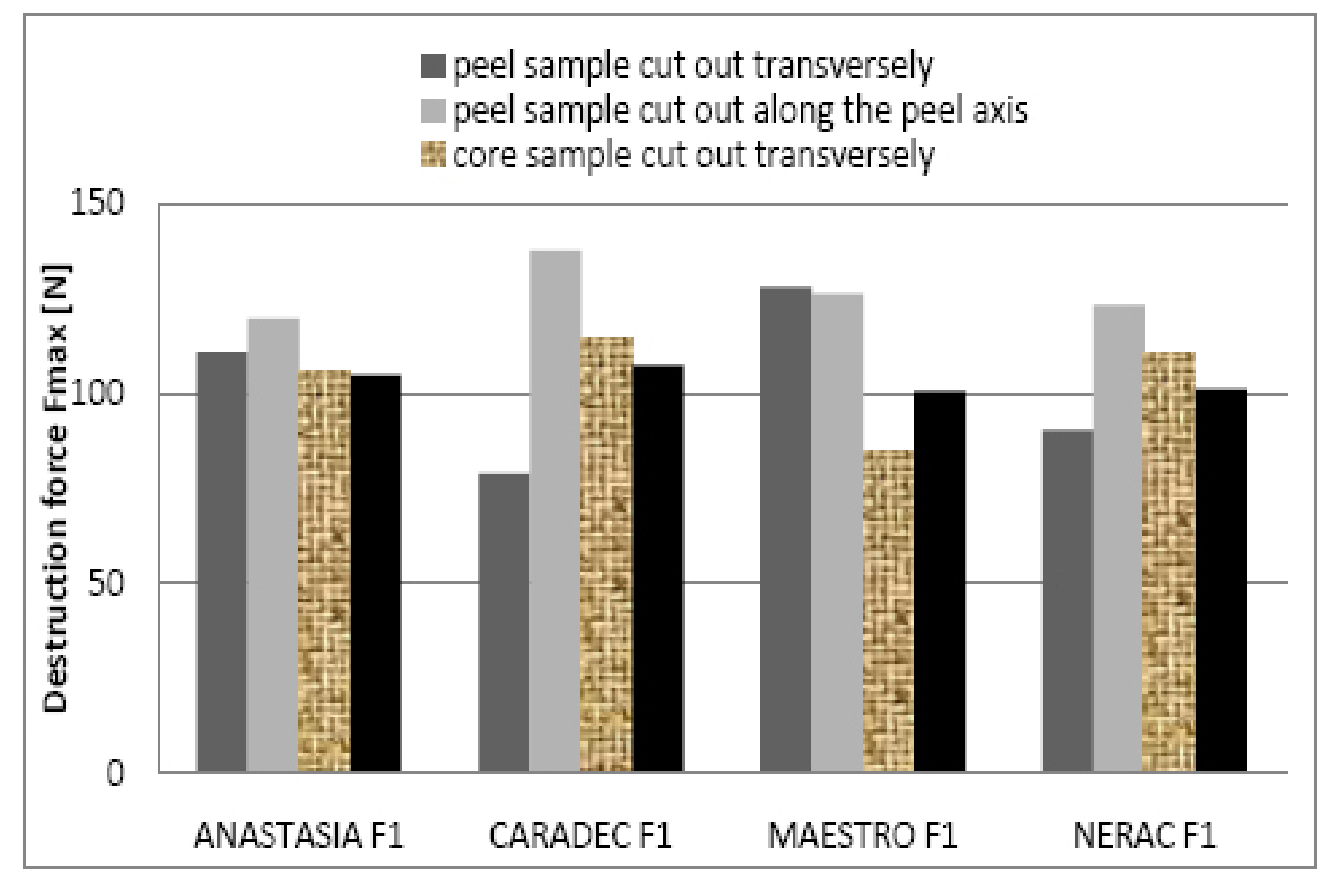

Fig10. Average values of Fmax destruction force for peel and core samples of investigated carrot varieties.

Table5. Average values of Fmax destruction force, Lmax strain directly before destruction, $\delta$ destruction stress and Eu apparent Young's modulus for peel and core of investigated carrot varieties.

\begin{tabular}{|l|l|l|l|l|}
\hline Variety & $\mathrm{F}_{\max }[\mathrm{N}]$ & $\mathrm{L}_{\max }[\mathrm{mm}]$ & $\delta[\mathrm{MPa}]$ & $\mathrm{E}_{\mathrm{u}}[\mathrm{MPa}]$ \\
\hline ANASTASIA F $_{1}$ & 110,6 & 3,13 & 2,07 & 5,30 \\
\hline CARADEC $_{1}$ & 111,0 & 2,98 & 2,11 & 5,67 \\
\hline MAESTRO F $_{1}$ & 116,7 & 2,85 & 1,89 & 5,32 \\
\hline NERAC F $_{1}$ & 106,3 & 3,06 & 2,33 & 6,10 \\
\hline $\mathbf{X}$ & $\mathbf{1 1 1 , 1}$ & $\mathbf{3 , 0 0}$ & $\mathbf{2 , 1 0}$ & $\mathbf{5 , 6 0}$ \\
\hline
\end{tabular}

The average value of destruction force in the process of uniaxial compression of root samples has amounted 111.1 $\mathrm{N}$ for all investigated varieties. Independently of the part of carrot root, from which the peel and core samples has been cut out, the highest resistance and, at the same time, the highest value of force required for cylindrical (free) sample destruction, has been stated for Maestro $\mathrm{F}_{1}$ variety. This force has amounted 116.7 $\mathrm{N}$. The average values of this force for Anastasia $\mathrm{F}_{1}$ and Caradec $\mathrm{F}_{1}$ varieties have been similar and amounted correspondingly $110.6 \mathrm{~N}$ and $111.0 \mathrm{~N}$. The lowest resistance or, in other words, the lowest value of destruction 


\section{American Research Journal of Agriculture (ARJA)}

force for the carrot root peel and core has been stated for Nerac $\mathrm{F}_{1}$ variety and has amounted $106.3 \mathrm{~N}$. The average value of relative strain directly before the moment of destruction of the carrot root peel and core sample has been stated within the range from $2.85 \mathrm{~mm}$ to $3.13 \mathrm{~mm}$. The average value of destruction stress for all varieties has amounted 2.1 MPa. The value of apparent Young's modulus has been equal to $5.30 \mathrm{MPa}$ for Anastasia $\mathrm{F}_{1}$ variety and 6.1 MPa for Nerac $\mathrm{F}_{1}$ variety. The highest energy required for destruction of the carrot root sample, equal $140.1 \mathrm{Nmm}$, has been stated for Anastasia $\mathrm{F}_{1}$ variety, while the lowest energy for sample destruction, equal $111.5 \mathrm{Nmm}$, has been noted for carrot root samples of Nerac $\mathrm{F}_{1}$ variety.

The dependence between the average value of $\mathrm{F}_{\max }[\mathrm{N}]$ force, destructing the carrot root peel and core, and the $\mathrm{L}_{\max }[\mathrm{mm}]$ strain is presented in Figure 11. This dependence can be expressed in form of trend line $y=\mathrm{x}^{2}+\mathrm{ax}-\mathrm{b}$. The values of $\mathrm{R}^{2}$ coefficients of determination, describing the dependence between the average value of force, destructing the carrot root peel and core, and strain, are very high and amount 0.81 and 0.83 .
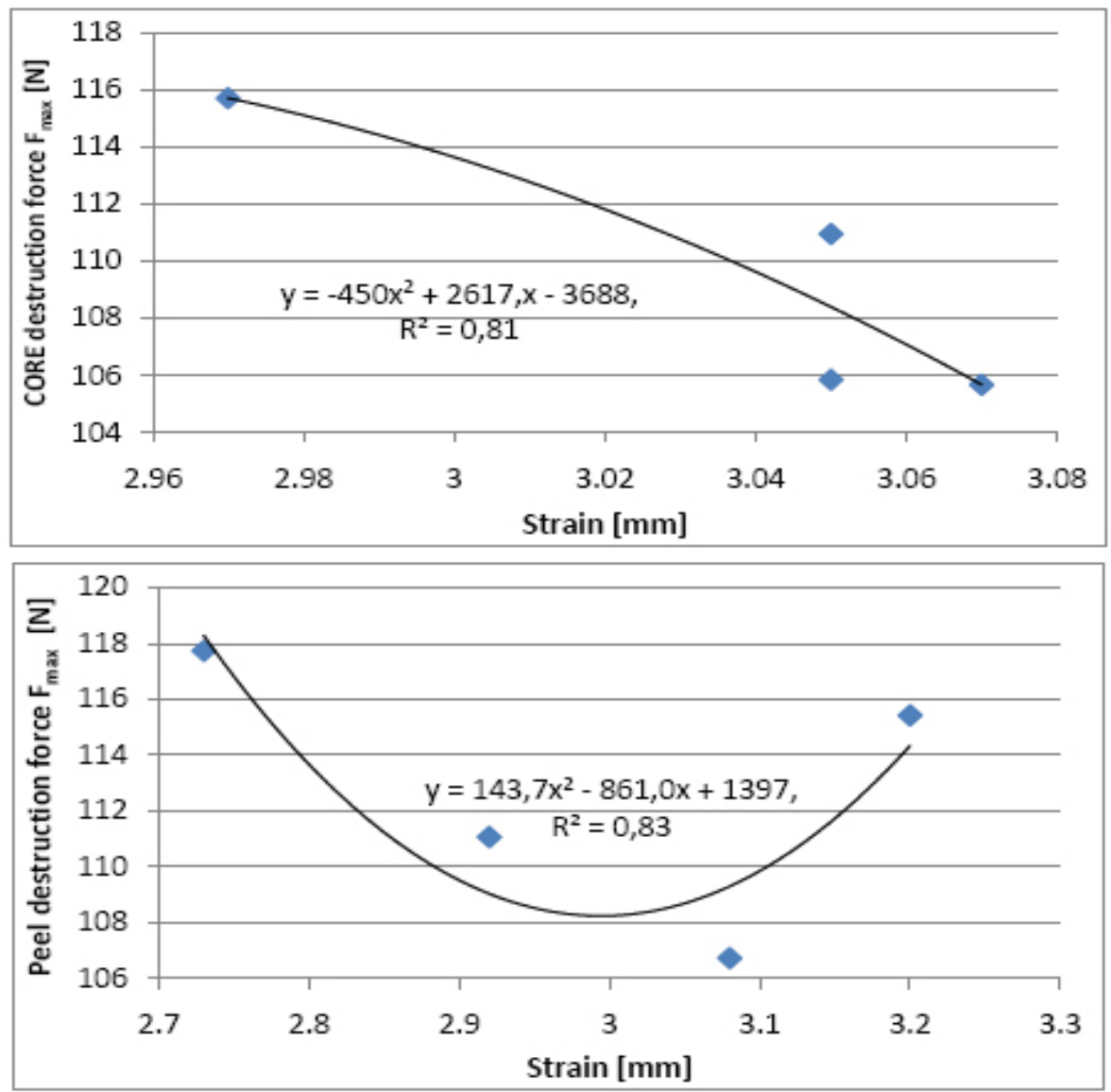

Fig11. Dependence between the average value of F[N] force, destructing the carrot root peel and core, and the strain [mm] in the investigated carrot varieties 


\section{CONCLUSIONS}

1. Differentiated chemical composition has been stated in storage roots of the investigated carrot varieties.

2. The average values of force of penetration with a punch of $5 \mathrm{~mm}$ diameter and destruction strains for carrot root peel and core have been stated in the range:

- penetration forces from $70.41 \mathrm{~N}$ for Anastasia $\mathrm{F}_{1}$ variety to $75.69 \mathrm{~N}$ for Caradec $\mathrm{F}_{1}$ variety,

- destruction stresses from 3.77 MPa for Anastasia $\mathrm{F}_{1}$ variety to 4.06 MPa for Caradec $\mathrm{F}_{1}$ variety

3. Strong dependence has been stated between the average value $\mathrm{F}[\mathrm{N}]$ of peel and core penetration force and percentage contents of water $\left(\mathrm{H}_{2} \mathrm{O}\right)$, nitrogen $(\mathrm{N})$ and sulphur $(\mathrm{S})$ in carrot roots, as well as $\mathrm{L}_{\max }[\mathrm{mm}]$ strains.

4. The average values of destruction forces for peel and core of the investigated carrot varieties have been stated in the range of $106.3 \mathrm{~N}$ for Nerac $\mathrm{F}_{1}$ variety to $116.7 \mathrm{~N}$ for Maestro $\mathrm{F}_{1}$ variety.

5. The average value of the apparent Young's modulus of the root peel and core (free samples) has amounted $5.59 \mathrm{MPa}$ in the investigated carrot varieties.

6. The average value of destruction stress for carrot root peel and core has depended of water contents (\%) in the roots and tissue type (peel and core). The average value of destruction stress have amounted $2.17 \mathrm{MPa}$ for Maestro $\mathrm{F}_{1}$ variety and $2.31 \mathrm{MPa}$ for Anastasia $\mathrm{F}_{1}$ variety.

\section{REFERENCES}

Ahmad B., Hassan S. and Bakhsh K., 2005. Factors affecting yield and profitability of carrot in two districts of Punjab. Int. J. Agric. Biol., Nr 7, str. 794-798.

Bahri M.H. and Rashidi M., 2009. Effects of coating methods and storage periods on some qualitative characteristics of carrot during ambient storage. Int. J. Agric. Biol. Nr 11, str. 443-447.

Bentini M., Caprara C., Rondelli V., Calicceti M., 2002. The use of an electronic beat to evaluate sugar beet damage at various forward speeds of a mechanical harvester. Trans, ASAE, Nr 45(3), str. 547-552.

Blahovec J., 1985. Jednoduchy model procesu stlacovani a mechanickeho poskazeni duznin. Zemedelska Technika, Nr 31 (6), str. 146-157.

Blahovec J., 2001. Static mechanic and texture of fruits and vegetables. Research in Agricultural Engineering, $\mathrm{Nr}$ 47(4), str. 144-169.

Bohdziewicz J., 2003. Wpływ zróżnicowania morfologicznego na zmianę parametrów modeli reologicznych miąższu wybranych warzyw korzeniowych. Acta Agrophysica, Nr 2(3), str. 499-508.

Bohdziewicz J., Czachor G., 2010. Wpływ obciążenia na przebieg odkształcenia warzyw o kształcie kulistym. Inżynieria Rolnicza, Nr 1(119), str. 85-91.

Bzowska- Bakalarz M., 1998. Badanie niektórych właściwości fizycznych korzeni buraków cukrowych. Zeszyty Problemowe Nauk Rolniczych, Nr 316, str. 9-14. 
Bzowska- Bakalarz M., 1998. Wytrzymałość mechaniczna korzeni buraków cukrowych, Zeszyty Problemowe Postępów Nauk Rolniczych, Nr 454, str. 207-2012.

Bzowska- Bakalarz M., 1999. Wskaźnik twardości tkanki korzeni buraków cukrowych, Zeszyty Problemowe Nauk Rolniczych, Nr 423, str. 314-320.

Czachor G., 2006. Dynamika procesów zachodzących w ściskanej tkance buraka ćwikłowego. Inżynieria Rolnicza, Nr 13(88), str. 69-77.

Fechner W., Buscher W., 2000. Elektronische Messrube mint sechs Beschleunigungssensorem. Landtechnik, Nr 55 (1), str.86-97.

Gajewski M., 2010. Czynniki wpływające na jakość marchwi przeznaczonej do przetwórstwa. Katedra Roślin Warzywnych i Leczniczych SGGW, Warszawa.

Gorzelany J., Puchalski Cz., 2000. Mechanical properties of sugar beet roots during harvest and storage. International Agrophysics, Nr 14(2), str. 173-179.

Gorzelany J., Puchalski Cz., 2005. Próba zastosowania metody nieniszczącej do badań właściwości mechanicznych buraków cukrowych. Acta Agrophysica, Nr 2(1), str. 61-71.

Gołacki K., Rowiński P., 2006. Dynamiczne metody pomiaru własności mechanicznych owoców i warzyw. Acta Agrophysica, Nr 8(1), str. 69-82.

Hussain I., Gilani S.N., Khan M.R., Khan M.T. and Shakir I., 2005. Varietal suitability and storage stability of mango squash. Int. J. Agric. Biol., Nr 7, str. 1038-1039.

Jakubczyk E., Lewicki P.P., 2003. Właściwości mechaniczne tkanki jabłka w odniesieniu do jej struktury. Acta Agrophysica, Nr 2(3), str. 549-557.

Jakubczyk E., Uziak D., 2005. Charakterystyka instrumentalnych metod badań właściwości mechanicznych wybranych owoców i warzyw. Inżynieria Rolnicza, Nr 11(71), str. 181-189.

Kamiński E., Stopa R., Stępień B., 2011. Zmiana nacisków powierzchniowych korzeni marchwi w funkcji czasu przy stałej wartości przemieszczenia początkowego. Inżynieria Rolnicza, Nr 4(129), str. 105-111.

Lentas K., Wiatrowa- Rejchert D., 2009. Wpływ parametrów blanszowania na właściwości mechaniczne i barwę suszu korzeni selera. Acta Agrophysica, Nr 13(1), str. 165-174.

Marzec A., Pasik S. 2008. Influence of dried method of the mechanical and acoustic properties of dried car. Inżynieria Rolnicza, $\mathrm{Nr}$ 1(99), str.76-87.

Mohsenin N.N., 1986. Physical Properties of Food and Agricultural Materials. Gordon and Breach Science Publishers, NY, U.S.A.

Mostofi Y. and Toivonen P.M.A. 2006. Effects of storage conditions and 1-methylcyclopropene on some qualitative characteristics of tomato fruits. Int. J. Agric. Biol., Nr 8, str. 93-96.

Nieć H., 1999. Warzywa korzeniowe i rzepkowate. Wydanie III, PWRiL, Warszawa.

Olewnicki D., 2009. Przemiany wybranych czynników ekonomicznych gospodarki sadowniczej i warzywnej w 
gospodarce żywnościowej w latach 1980-2008. Zeszyty Naukowe Instytutu Sadownictwa i Kwiaciarstwa im. Szczepana Pieniążka, Tom 18.

Peleg M., 1984. Considerations of general rhreological model for the mechanical behaviour of viscoelastic solid food materials. Journal of Texture Studies, Nr.15, str.243-256.

Pitt R. E., 1982. Models for the rheology and statistical of uniformly stressed vegetation tissue. Trans. of ASAE, Nr 25 (6), str. 1776-1784.

Rashidi M., Bahri M.H. and Abbassi S., 2009b. Effects of relative humidity, coating methods and storage periods on some qualitative characteristics of carrot during cold storage. American-Eurasian J. Agric. and Environ. Sci., Nr 5, str. 359-367.

Rashidi M., Bahri M.H. and Khabbaz B.G., 2009a. Effects of coating methods and storage periods on some quality characteristics of carrot during ambient storage. In. Proc. of Biennial Conference of the Australian Society for Engineering in Agriculture (SEAg), Nr 9/2009, str.13-16.

Rashidi M. and Khabbaz B.G. 2010. Prediction of total soluble solids and firmness of carrot based on carrot water content. In: Proc. of XVII ${ }^{\text {th }}$ World Congress of the International Commission of Agricultural and Biosystems Engineering (CIGR), Nr 7, str. 13-17.

Sady W., Robak J., Więch K, 2000. Uprawa marchwi. Plantpress, Kraków.

Sharma H.K., Kaur J., Sarkar B.C., Singh C., Singh B. and Shitandi A.A. 2006. Optimization of pretreatment conditions of carrots to maximize juice recovery by response surface methodology. J. Eng. Sci. Tech., Nr 1, str. 158-165.

Sitkei G., 1987. Mechanics of agricultural materials. Akademiai Kiado, Budapest.

Stopa R., Romański L., Jankowski L., 2008. Obrazy izochrom w modelu przekroju poprzecznego korzenia marchwi dla różnych wartości sił spójności warstw kory i rdzenia. Inżynieria Rolnicza, Nr 5(103), str. 283-290.

Suojala T., 2000. Variation in sugar content and composition of carrot storage roots at harvest and during storage. Sci. Hort., Nr 85, str. 1-19

SzczepańskiK.,Rejman S.1987.The methodology of fruit-growing researches (in Polish):78-80

Szot B., Gołacki K, 1978. Ocena właściwości mechanicznych korzeni marchwi na podstawie podstawowych parametrów wytrzymałościowych. Zesz. Prob. Post. Nauk Roln., Nr 321, str. 58-64.

Ullah H., Ahmad S., Anwar R. and Thompson A.K. 2006. Effect of high humidity and water on storage life and quality of bananas. Int. J. Agric. Biol., Nr 8, str. 828-831.

Citation: Gorzelany Józef, Matłok Natalia, Investigation of Mechanical Properties and Chemical Composition of Root Vegetables on the Example of Carrot Roots. ARJA Volume 2016; pp:1-17

Copyright (C) 2016 Gorzelany Józef, Matłok Natalia. This is an open access article distributed under the Creative Commons Attribution License, which permits unrestricted use, distribution, and reproduction in any medium, provided the original work is properly cited. 